\title{
Many Reasons for Leaving Afghanistan: Social Obligations in Times of Protracted Violence
}

\author{
Gabriele Rasuly-PALECZEK, Vienna
}

\section{Content}

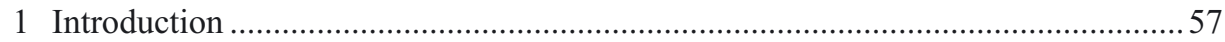

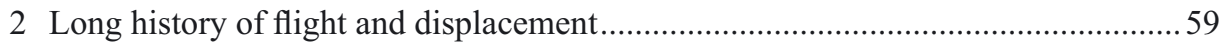

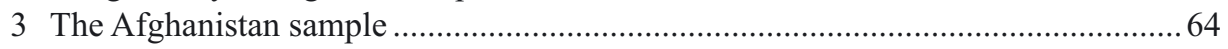

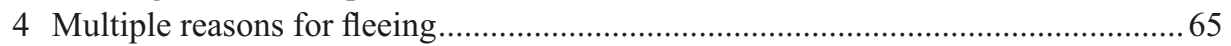

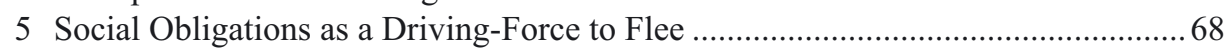

6 Supporting the flight of others: another social obligation ...................................... 75

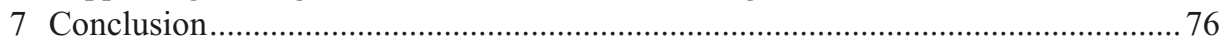

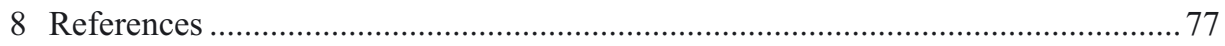

„....the threats increased, as long as I had a possibility to live, I did not emigrate, but when I came to the point that there was not any room for me, that if I remain, I will be killed, that if I remain, my family will still be menaced, I fled and left Afghanistan."

\section{Introduction}

Most current studies on refugees and asylum seekers coming to Europe focus on the reasons for fleeing (mainly personally experienced violence, economic issues, or a combination of the two), the challenges they face during their flight (e.g. struggles with

Quote from a A 13, a 36 year old Hazara from Ghazni 
human traffickers, border controls, imprisonment in camps in transit countries, hardship of flight, etc.) and their experiences in potential host countries. ${ }^{2}$

So far little attention has been paid to the relevance of personal motives (e.g. fleeing to avoid a forced marriage or to escape an ongoing vendetta) and to the importance of social obligations and relations in the context of forced migration (e.g. the felt necessity to flee to save the life of one's children or other family members or to offer one's children a better future). Most studies that do refer to social relations in the context of displacement and flight have highlighted the role of the latter in facilitating the establishment of refugees in their new places of residence (e.g. providing jobs, housing and a first orientation in the new environment) or have analysed the transnational connections of refugees with their relatives and friends left behind or in other locations of refuge. ${ }^{3}$ Some studies have also analysed the role of social networks for the reintegration of returning refugees in their former home region and/or in preventing people from becoming refugees at all by successfully securing a sustainable livelihood despite protracted war or civil war (cf. Berg HarpViken 2009).

As the above quotation illustrates, asylum seekers not only flee due to personally experienced threats, but are also motivated by the responsibilities towards their loved ones. Using data from the Afghan sample of the pilot study, this chapter aims to highlight the oftentimes neglected intersection of social ties and obligations and reasons for fleeing, including very personal one's such as forced marriage. ${ }^{4}$

To contextualise our empirical data a brief outline of the long history of dispossession and displacement of Afghan refugees as well as their main reasons for taking refuge in Europe today will be offered. Following that, the motives of our twenty interviewees for fleeing will be summarised.

However, while most studies merely investigate the reasons for forced migrations (e.g. personal death threats, persecution on ethnic or religious grounds, economic

\footnotetext{
2 For details cf. Crawley et al. 2016; Healy 2016, ICG 2016, IOM 2016, De Bel-Air 2016, Brücker et al. 2016, Bjelica 2016 a, Donini, Monsutti and Scalettaris 2016, Echavez et al. 2014, LinKe 2016, Hansen 2014, Marfleet 2011.

3 Cf. Monsutti 2005, Monsutti et al. 2006, Collective for Social Science Research 2006, Stigter and Monsutti 2005, Kazemi 2016, Ceung and Phillimore 2013, Castles 2003, Van Hear 2014; cf. studies on the use of social media and i-phones by refugees. WitTENBORN 2015, ROHDE et al. 2016, Kondova 2016 and Kaufmann 2017.

${ }_{4}$ The pilot study investigated the life experiences of refugees in their home country or last place of residence, their reasons for leaving, the obstacles they experienced during their flight, including short-term refuge in Turkey and their first experiences in Austria. The study covered a total of sixty narrative interviews with asylum seekers from Syria, Iraq and Afghanistan (twenty for each group). The interviews were conducted from December 2015 to April 2016 by nativespeakers in Arabic, Farsi-Dari, Pashto und Kurdish (Sorani) and were later transferred into English and German transcript.
} 
hardships etc.), or describe the flight as an ongoing process, this contribution will transcend this approach.

Assuming that the decision to flee is not influenced by personal concerns (e.g. fearing being killed by insurgents) alone, but is also closely linked to the social obligations the individual bears for their social environment (e.g. children, wife, kinsmen), the significance of these social obligations (e.g. protecting the life of family members and kin, offering their children a better future) for the decision-making process will be analysed. As the latter rarely refer to the decision-making process alone, other activities connected to these social obligations (e.g. organising and facilitating the flight of children and other family members by providing financial and other support) will be focused on as well.

And finally, the relevance of personal motives - mentioned in several of our interviews - as reasons for a forced migration will be tackled.

\section{Long history of flight and displacement}

Since the communist coup d'etat in April 1978 and the Soviet invasion in 1979 Afghans have been exposed to war, civil war and the use of force by non-state armed groups (e.g. the Taliban, Al-Qaida and most recently ISIS, criminal gangs, war and drugs lords, etc.) as well as by Afghan government forces (army, policy and "arbaki" = Afghan local police) and the international supports (the Soviet army from 1979-1989; ISAF troops since 2001). This protracted violence has turned millions of Afghans into IDP's and refugees, often repeatedly.

Until the beginning of the civil war in Syria, Afghans - for 34 consecutive years - constituted the single largest refugee population in the world. Following the Soviet invasion in December 1979, more than 5 million (approx. one third of the total population) fled the country (GRÖTZBACH 1990, p. 60). Another between 1 and 1.5 million were killed or maimed (cf. SLIwINSKi 1988). Most of them became refugees in Iran (around 2.5 million) and Pakistan (around 3.5 million). Only a small number - mostly well-off and better educated Afghans - moved to Europe and North America (cf. KUSHKAKI 1990, p. 115 f; RiesenKAMPFF and NoOr EBAD 2017).

With the defeat of the communist regime in April 1992, millions of Afghan refugees returned home only to become refugees or internally displaces persons (IDPs) shortly afterwards when civil war broke out between various mujahedin groups. The latter culminated in the nearly total destruction of Kabul and a fractionalisation of the 
country into various chiefdoms led by warlords and local power holders. Once again hundreds of thousands of Afghans were displaced (cf. Glatz 2015, Pro Asyl 2016, p. 25; FMR 2014).

Following the Taliban's rise to power in 1996, the displacement and persecution of civilians (in particular the Shia Hazara population) continued (HuMAN RigHTS WATCH 1988 and 2001). As a consequence of military confrontations between the Taliban forces (predominantly Pashtun fighters) and the Northern Alliance (a coalition of former mujahedin fighters of Tajik, Uzbek and other ethnic background), a further one million people were displaced, mostly in the northern and central parts of the country (cf. GLATZ 2015).

With the final defeat of the Taliban regime in early 2002 and the installation of a new government, millions of Afghan refugees started to return home - sometimes after decades in exile in Iran, Pakistan and Western countries. ${ }^{5}$ At the same time new displacement occurred, especially in the southern and eastern parts of Afghanistan where the US-led fight against al-Qaida and Taliban networks (e.g. in Helmand) continued provoking large scale internal displacement of civilians that were caught between the lines. ${ }^{6}$

Hopes for a return to some kind of normalcy after decades of warfare soon faded. Despite vowing to bring peace, stability and reconstruction to the war-ravaged country, the new power holders and their international supporters were incapable of fulfilling their promises. Afghanistan once again plunged into a political crisis prone to corruption, illegitimacy and insurgency.

Since around 2009 the security situation has begun to deteriorate once again in many parts of the country (especially in Eastern and Southern Afghanistan). By the end of 2014 - when most of the foreign troops left Afghanistan - the Taliban and other insurgency groups (e.g. Islamic Movement of Uzbekistan operating in the northeast and most recently ISIS in Nangahar province, eastern Afghanistan) were regaining ground.

As of today, insurgency groups - in particular the Taliban - control nearly half of all districts and have repeatedly been able to temporarily conquer urban areas (e.g. the city of Kunduz in September 2015 und October 2016) and launch attacks, even in the high security areas of Kabul (e.g. on the Afghan parliament in mid-2015, the Russian Embassy on January $20^{\text {th }}$, 2016, a military hospital in Kabul in March 2017 and most recently the diplomatic quarter of Kabul at end of May 2017). ${ }^{7}$

\footnotetext{
According to UNHCR figures more than 5.8 mill. Afghans returned from Iran and Pakistan between 2004 and 2014 (cf. UNHCR 2015).

$6 \quad$ Its peak occurred in 2002 with 1.2 mill. (GLATZ 2015).

7 re security situation in Afghanistan and its development: cf. SIGAR 2017, EASO 2016, Clark 2017; Pro Asyl 2016 and Norwegian Refugee Council 2017.
} 
The deteriorating security situation and the persisting confrontation between insurgent groups and government forces and their international supporters has led to a significant rise in the number of civilian casualties and to renewed displacement in many parts of the country. ${ }^{8}$

Displacement and dispossession has become a widespread experience for many Afghans. Each regime change (e.g. communist coup d'etat, establishment of the mujahedin government in 1992, the Taliban regime from 2016 to 2001) set in motion new waves of displacement, which were sometimes followed by repatriation and renewed flight. The protracted violence not only produced millions of refugees and IDPs, but also led to an extensive destruction of sources of livelihood (e.g. irrigation systems, orchards, deforestation, mining of fields and pastures) and the replacement of formerly existing local modes of conflict resolution via traditional mediators (e.g. tribal leaders, village elders). They have been replaced by what became known as "kalashnikov culture", that is the resolution of conflicts by violent means (cf. GoODSON 2001, pp. 91-132).

Nearly two generations of young Afghans have grown up in an atmosphere of fear, mistrust and uncertainty. Many have experienced the death and/or disfigurement of close family members and friends and are traumatised by longstanding exposure to violence and a constant struggle for survival as refugees, IDPs and returnees. The long-standing violent conflict and recurrent displacement has diminished the resilience of many Afghans and has often overstretched the coping strategies of social networks (family, kin groups). The latter have become more and more fragile. Social relations are increasingly shaped by fear and a lack of trust.

The situation is aggravated by the inability of the Afghan government to provide good governance and to care for the most vulnerable (e.g. IDPs, returning refugees, widows and orphans). ${ }^{9}$ Particularly precarious is the situation of protracted IDPs and returning refugees, who find it extremely difficult to start a new life. Most of them cannot return to their original place of residence as their land is now occupied by others. Many returnees (especially those who left decades ago or those born in exile) have little recourse to local networks that are crucial for finding jobs or borrowing money to finance a new beginning (cf. PRO ASYL 2016). Numerous returnees and newly displaced

\footnotetext{
Re: Civilian casualties: cf. Pro Asyl 2016, UNAMA 2017 a. Between 2014 and 2015 civilian casualties increased by $141 \%$ (CLARK 2016).

Re: IDP's: cf. BJelicA 2016 a, IOM 2014, OCHA 2017 a, OCHA 2017 b, Pro Asyl 2016, and Samuel Hall Consulting (2014). IDP's figures increased from approx. 400.000 in 2012, to 828.000 in 2014 reaching 1.797 mill. in May 2017 (compiled according to Pro AsYL 2016, SAMUEL Hall Consulting 2014, Buelica 2016 b, OCHA 2017 a. In 201631 of the 34 provinces faced some forced displacement; cf. BJELICA 2016 b and 2017; OCHA 2017 b. From January $1^{\text {st }}$ to May $21^{\text {st }}$ 2017 alone 101,380 new IDP's (OCHA 2017 b).

9 re: Afghan government does no care for returnees and IDP's Pro AsyL 2016 and SIGAR 2015. According to data from OCHA (2016) Afghanistan 1 out of 4 Afghans (in total 9.3 mill.) are in need of humanitarian assistance.
} 
persons end up in precarious living circumstances in urban and peri-urban settlements with no access to housing, land, water, education or health services. ${ }^{10}$

Many Afghans in the meantime have become disillusioned. They have lost all hope of an end to the violence and a better future and are looking for alternative options to bring some normalcy to their lives.

Yet, while Pakistan and Iran had initially (since 1979) been the main destinations for Afghans fleeing conflict, persecution and economic hardship, this is less so today. In both countries Afghan refugees - once well received - are now confronted with xenophobia and deteriorating living conditions. They have become scapegoats for all kind of local problems (e.g. shortage of labour, extensive drug use, sectarian conflicts, spreading their "kalashnikov-culture").

Following the end of the Taliban regime in 2002 they were expected to return home. Although around 5.8m Afghans were repatriated between 2004 and 2014, some 900,000 refugees remained in Iran and another 1.4m in Pakistan. (cf. OCHA 2017 c). ${ }^{11}$ Since 2012, the governments of Iran and Pakistan have notably increased their efforts to substantially reduce the number of Afghan refugees. By aggravating their living conditions (e.g. closing refugee camps in Pakistan, restricting the movement of Afghan refugee in Iran, cutting down support programs, limiting access to employment, health and educational facilities) both governments try to pressure Afghan refugees to voluntarily return to their home country. In addition, both countries have intensified their deportation measures. ${ }^{12}$

Exposed to an official policy of progressively worsening intimidation and discrimination, and the threat of being deported from their former potential host countries Pakistan and Iran, many Afghan refugees are looking for alternative countries of refuge (e.g. moving from Iran to Turkey, fleeing to Europe or Australia). ${ }^{13}$ Since 2014 the number of Afghan asylum seekers - either coming directly from Afghanistan or

\footnotetext{
10 According to OCHA 2015 approx. 50\% of IDP's need shelter, 3 out of 5 refugee families are in need of assistance, 4 out of 5 IDPs require food assistance and 3 out of 5 IDP children do not attend school. For details on the situation of returning refugees cf. MuZHARY 2017.

${ }_{11}$ No exact data is available and it is assumed that several million undocumented Afghan refugees are still residing in Iran and Pakistan (GLATZ 2015).

12 Deportation from Iran: cf. UNHCR 2013, IOM 2015, Human Rights Watch 2013. According to PRo AsYl (2016, p. 28) 192,000 deportations and 317,000 more or less "voluntary" returns occurred from January to October 2015.

Deportations from Pakistan: cf. Glatz 2015, Human Rights Watch 2017, BJelica 2016 c and 2017, IOM 2015 and 2017, OCHA 2017 c and Pro AsYL 2016. According to UN data some 616,411 Afghans returned from Pakistan in 2016 (BJELICA 2017). From January to May 2017 96,875 Afghans were repatriated (OCHA 2017 c).

${ }_{13}$ re: Fleeing from Iran and Pakistan: RiesenKAmpfF and Noor Ebad 2017; Pro Asyl 2016, p. 29; re. situation of Afghan asylum seekers in Turkey CHESLOw 2016; Turkey as a transit country, cf. TAN in this volume.
} 
from Iran and Pakistan - fleeing to Europa has steadily increased from less than 30,000 in 2013 to more than 41,000 in 2014, reaching a peak of around 200,000 in 2015. ${ }^{14}$

Austria is one of the main destination countries in Europe. According to official Austrian statistics, Afghan asylum seekers constitute the largest group, slightly exceeding the number of Syrians. From a total of 88,151 asylum applications in $201529 \%$ or 25,475 were submitted by Afghan nationals (from Syria $28 \%$ or 24,538 individuals and from Iraq $15 \%$ or 13,602 ) (BMI 2015). Although the overall number of asylum seekers decreased substantially in 2016 (only 42,073 applications), refugees from Afghanistan once again constituted the largest individual group $(27.9 \%$ or 11,742 persons, Syria $21.02 \%$ or 8,845 individuals; Iraq $6.74 \%$ or 2,837 ) (BMI 2016). ${ }^{15}$

Among the asylum seekers currently arriving in Europe are people from very diverse backgrounds (well-educated and better off as well as illiterate and poorer refugees of different ethno-linguistic and religious origins) (cf. RIESENKAMPFF and NoOR EBAD 2017, p. 1 seq.). Most of them are young men, among them many who have spent years in exile or have been born there (e.g. in Iran), but now fear being forcibly repatriated to Afghanistan, a country they barely know or where they have no economic resources or social networks to resettle.

According to a recently conducted study by Donini, MonsutTi and SCALETTARIs, four different groups of Afghans are currently coming to Europe. "1) unaccompanied minors and young adults (often coming from Iran), 2) Adults (mostly men age 20 to 35 years) deriving from southern Afghanistan ("Pashtun Belt") where conflict between Afghan government and Taliban is esp. fierce. 3) Afghans who had worked for international organizations, NGOs or troops and now - as the Taliban are getting stronger and the security situation is subsiding - fear revenge killings and abductions by Taliban and others (this group may also include some women) and 4) Young Afghans educated by foreign organizations who feel alienated in today's conservative Afghanistan." (MonsutTi 2016, p. 15 seq; for details cf. Donini et al. 2016)

14 for details cf. Ruttig 2017, RiesENKAmpFF and Noor EbAd 2017, Donini et al.et al. 2016. According to EuROSTAT data a yearly average of 18,000 Afghans applied for asylum between 2008 and 2013. Since 2016 the number of Afghans applying for asylum in the EU has sharply declined from 57,200 (last quarter of 2015) to 22,000 last quarter of 2016 (cf. Asylum quarterly report: data extract 15 March 2017).

15 Only since the beginning of the year 2017 the number of Afghan asylum seekers began to drop substantially. From January to March 2017, 1,133 Afghans (=17.48\% of all applications) applied for asylum, as compared to 1.908 or $29.44 \%$ from Syria and $365=5.63 \%$ from Iraq (BMI 2017).

Among unaccompanied minor refugees (UMR) (below 14 to 18 years) Afghans still constitute the largest group. From a total of 575 UMF (January to March 2017) 48.17\% (or 277 persons) were Afghans, 4.34\% Syrian UMF (25 persons) and 2.97\% (or 17) from Iraq. (BMI 2017). In 2015 a total of 8,380 UMR had been registered in Austria. 5,676 persons (68\% of all UMR) were of Afghan origin (BMI 2015). Cf. details on UMR coming to Europe BoLAND 2010 and UNHCR 2010 . 


\section{The Afghanistan sample}

This diverse background of asylum seekers from Afghanistan is also reflected in the twenty interviews of our pilot study. The majority (17 persons) were single male. Two of the three Afghan women migrated together with their husbands. ${ }^{16}$ Most of our interviewees (11 out of 20) were aged 20-29 years, another six from the age group 30-39 years and only two persons were older than 50, thus reflecting the overall impression that it is basically young males that migrate to Europe. ${ }^{17}$

Our sample encompassed members of a large variety of different ethno-linguistic and religious groups. Half of the Afghan refugees and asylum seekers were Pashtuns originating from the south-eastern part of the country or from Kabul. Hazara - either directly from Afghanistan or from Iran, where they had spent long years in exile constituted the second largest group. ${ }^{18}$

Due to nearly four decades of protracted violence our interviewees or their relatives have experienced earlier internal displacement (cf. A 6, A 17) or periods of taking refuge in neighbouring countries (Iran and Pakistan) (cf. A 2, A 5, A 6, A7, A 20) before finally arriving in Austria. Some even moved from Iran to Pakistan and vice versa (cf. A 17). Others returned to Afghanistan, but due to the security situation (cf. A 2, A 16 and A 19), problems of adapting to their original home country (e.g. A 18, who had been born in Iran) or other reasons renewed their flight (A 1, A 10, A 12 and A 15). (cf. details below).

A good case illustrating this multi-displacement experience of many Afghans is A 17, a 21-year-old male Shia Hazara. His father had been a police officer. Due to the difficult security situation and the lack of educational possibilities the father of A 17 decided to move first from the home village to Ghazni (a provincial capital centre in Southern Afghanistan). As the security deteriorated further and threats from the Taliban against the Hazara population increased, A 17 and his family left for the Pakistani city Quetta. ${ }^{19}$ Finding it difficult to live in Pakistan where Shia are discriminated against, the family moved on to Iran. However, once again they found themselves in a precarious

\footnotetext{
16 The third Afghan female travelled alone to join her husband already living in Austria. According to official Austrian statistics the majority of recent asylum seekers are male $(72.4 \%$ in 2015; 67.04\% in 2016, vgl. BMI 2015 and BMI 2016, Dec.) No breakdown according to country of origin was published.

17 For one person no data was available. For general figures on asylum seekers cf. figure 4: distribution by age of (non-EU) first time asylum applicants in the EU and EFTA Member States, 2015 (last updated 18-03-2016); (EUROSTAT 2017).

18 For information on the ethnic and religious background of Afghan asylum seekers see RIESENKAMPFF and NoOR EBAD 2017, Donini et al. 2016.

${ }_{19}$ Quetta is a long standing centre of the Hazara diaspora in Pakistan, for details cf. MonsutTI 2005.
} 
situation. A 17 was finally sent to Europe by his father in search for a better future. The rest of his family later migrated to Australia. ${ }^{20}$

\section{Multiple reasons for fleeing}

In line with other studies highlighting the reasons for taking refugee (cf. BRÜCKER et al. 2016, Crawley et al. 2016, Donini, Monsutti and Scalettaris 2016, Linke 2016; ICG 2016, IOM 2016, FMR 2014, De BeL-Air 2016, Kazemi 2016, EchaveZ et al. 2014), our Afghanistan data shows that it is usually a combination of causes that influenced the decision to flee or to renew a flight. Here it is often a mixture of general security concerns and experienced violence as well as economic and other reasons (e.g. being persuaded by friends to join a flight, evading an unbearable domestic situation, fleeing from an ongoing vendetta, being discriminated in current place of residence, e.g. in Iran) that plays a role. All these flight motives are often closely linked to social obligations (e.g. preserving the life of family members, offering children a better life) as will be illustrated below.

Regarding security related issues, many of our interviewees mentioned increases in local violence, suicide attacks, fear of abduction by oppositional groups and/or criminals and the heightening of ethnic and religious conflicts. Several also highlighted the assassination of a close family member (cf. A 7, A 14, A 16) personal death threats, detention by government and/or opposition groups (brother of A 16), reprisals by Islamic radicals (Taliban, ISIS or Daesh) for not subscribing to their rules (A 13 and A 15) or for not actively supporting their cause (e.g. helping them to organise a suicide attack at their workplace in a foreign NGO, cf. A 2, A 3, A 16), or retaliations for having worked for foreigners (e.g. US forces) (A 3 ) as reasons for finally fleeing. ${ }^{21}$

The reasons for fleeing may be different for various groups of Afghans. While Pashtuns and others may perceive increases in local violence and suicide attacks as the main driving force informing their decision to finally leave the country, Hazara from Afghanistan (A 5, A 7 and A 13) and other Shiites (A 14) often feel threatened by the Taliban, and more recently by Daesh, who do not consider Shia Muslims proper Muslims. ${ }^{22}$

$20 \quad$ Living conditions for Afghan refugees have considerably deteriorated in Iran since 2001; cf. above.

${ }^{21}$ The fathers of A 7 and A 14 were killed by the Taliban; the brother of A 16 was abducted by the Taliban and later killed by them. The brother of A 15 was eventually killed in a vendetta that resulted from violating the ban on music played at his wedding; for details see below. A 13 was persecuted for disseminating a radio programme that was considered un-Islamic by the Taliban.

22 cf. persecution of various ethnic groups, e.g. Pashtun and Hazara Pro AsYL 2016; re persecution of Hazara population, e.g. Taliban massacres in 1998 and 2001, Human Rights Watch 1998 and 2001. 
Next to ethnic and religious minorities it is often women (in particular widows, e.g. mother of A 7 and A 10) and orphans (A 14) whose security is at stake, especially when they belong to ethnic or religious minorities (cf. A 7, A 10 und A 14; for details see below) ${ }^{23}$ An illustrative case is A 14, a 20 -year-old male Shiite from Herat, whose father was killed by the Taliban. Soon afterwards his mother died. A 14 moved in with his maternal aunt. Being a Shiite he felt threatened by the Taliban. Eventually the husband of his maternal aunt organised his flight.

Another group in our dataset that was particularly exposed to threats were individuals who had been working for Afghan governmental agencies or foreign organisations (e.g. as translators or security personnel for NATO or NGOs like GTZ24) (cf. A 2, A 3, A 4, A 8, A 9, A 16 and A 19, for more details cf. below). These people either were persecuted for not supporting the Taliban in infiltrating their workplace to instigate a suicide attack (e.g. A2, A 3 and A 16), or received threats for working with 'kufr' ('unbeliever', a term used by the Taliban for foreigners) as in the case of A 3, a 24-year-old Pashtun from Nangahar highlights. ${ }^{25}$ "I have worked for them [note: GTZ] for roughly two years... On the part of IS we received many threats, they voiced the opinion that we should not work together with 'unbelievers'."

In addition, to security related concerns many of our interviewees also voiced a general disillusionment about the current political situation in Afghanistan (e.g. lack of good governance, a high level of corruption) and their personal future perspectives in their country of origin or former place of residence, e.g. Iran and in terms of employment, professional advancement or educational possibilities) (cf. A 5, A 13).

This perception is well articulated by the following quotations from our interview with A 5, a 25-year-old Hazara, who spent many years in Iran. "In my opinion the situation will not improve within the next hundred years. The government of Afghanistan will never be a stable one, for 40 to 50 years there is war. Since 10 to 12 years the principle of the stronger rules [es herrscht das Prinzip des Stärkeren], tribes fight against each other. I do not think that the situation in Afghanistan will improve within the next hundred years." (A 5, male, 25, Iran, Hazara, Shiit). A 12, an approx. 50-yearold Pashtun from Kunar had the following to say: “...in my opinion the situation will never improve, the homeland is sweet, but once it is destroyed, it will remain destroyed forever."

Besides the above-mentioned reasons, increased discrimination on ethnic and/or religious grounds in the initial place of refugee (e.g. Iran and Pakistan) or transit country

23 Re: Situation of Afghan women, cf. LOCKET 2010.

24 In January 2011 the German Organisation for Technical Cooperation (GTZ) was transformed into the Deutsche Gesellschaft für Internationale Zusammenarbeit (GIZ).

25 Particularly threatened are translators and security personnel working for foreign NGOs and troops, cf. Frud 2012, The Telegraph 2017 and Spiegel online 2013. 
(e.g. Turkey) were highlighted by several of our interviewees as causes informing their decision to finally leave for Europe. ${ }^{26}$

A 5, a 25-year-old Hazara, who came as a child to Iran and spent more than 20 years there described the situation of Afghan refugees as follows: "Afghans in Iran have no easy life.... An Afghan must work until he dies, he has no insurance, he has to pay for his education, his medication ... an Afghan is treated like an animal, he has no rights...". A 4, a 54-year-old male Pashtun from Kandahar, who was a short term refugee in Iran, highlighted: "I have been a refugee in Iran, they did not provide us with any food. And when I was walking around in my Afghan cloth, they called me an 'Afghan donkey'..."

Besides all the above mentioned reasons, several of our interviewees voiced very specific personal motives for their flight, e.g. having been persuaded by a friend to flee (A 18), avoiding a forced marriage (A 10), escaping an ongoing personal vendetta (A 15) or an unbearable domestic situation due to conflicts with their mother-in-law (A 7 , wife of A 6), finding it impossible to adapt to the home country upon return from a long period in exile (A 18) or trying to escape capital punishment for having broken social norms (A 5) or fleeing to join a husband living in Austria (A 1).

An illustrative case for these personal motives is A 5, a young Afghan living in Iran who was involved in a consensual, premarital sexual relationship with the sister of his friend. One day they were caught by the young woman's brother while making love. The latter threatened to report A 5 to the Iranian police for having raped his sister. Fearing a death sentence, A 5 immediately left the country.

Yet, even in cases where personal motives were the main reasons for fleeing, other factors (e.g. general security concerns, discrimination on the labour market, etc.) may also have an impact, as the case of A 18 illustrates. He was born in Iran where his family had fled to during the Soviet occupation of Afghanistan (1979-1989). Following the defeat of the Taliban regime his family returned to their country of origin. Like many other refugee children born in exile A 18, a young Hazara born in Iran, felt alienated there. ${ }^{27}$ "... Afghanistan was not what I had expected, the gap between the rich and the poor was very big. One person was extremely rich and the other very poor, a middleclass did not exist... I did not like Afghanistan, the country was not safe ..." Spending a year in the home country of his parents, A 18 returned to Iran, where due to increased discrimination of Afghan refugees, he was unable to find a job. Persuaded by a friend, he finally left for Europe.

\footnotetext{
26 Several of our interviewees had spent years in Iran and Pakistan or were even born. Re: on general situation of Afghan refugees in Iran and Pakistan cf. text above; on situation of Afghan refugees and transit migrants in Turkey, cf. CHESLOW 2016 and TAN in this volume.

27 cf. Saito 2007 and 2009; Saito and Hunte 2007.
} 


\section{Social Obligations as a Driving-Force to Flee}

As well as all the previously mentioned reasons, social obligations (e.g. fulfilling expected role models, revenging the death of a kinsmen, etc.) also play an important role in the pre-flight decision-making process. Afghans usually feel a strong responsibility for the wellbeing of their family and kinsmen (e.g. providing physical safety, offering them a "good life"). These obligations do not refer to their immediate family (e.g. wife and children) alone, but also encompass their extended family and social network (e.g. friend and work colleagues). In view of decades of warfare and a state that does not properly care for its citizens, sustainable social networks are crucial to guarantee a person's survival. Yet, the resilience and coping strategies of these networks have been badly effected by years of protracted violence, displacement and economic hardship. Still, many of our interviewees mentioned a strong commitment towards fulfilling social obligations, even if doing so may pose a challenge as the case of A 1 illustrates. A 1, a former high school student originally living in Kabul had been married against her will at the age of 14 to the son of her maternal uncle residing in Vienna. Being below the officially accepted age of marriage in Austria she could not apply for a visa, but had to travel illegally to join her husband and in-laws in Vienna.

While the flight of A 1 was linked to a personal obligation (a wife being requested to live with her husband), in most other cases in our Afghan sample the decision to flee was intimately connected to the obligation to protect the life of family members (e.g. children, parents or other close relatives) and/ or to offer them better opportunities (e.g. a life in peace, access to education) than those available at the current place of residence (e.g. Afghanistan, Iran or Pakistan, cf. e.g. cases A 4, A 6, A 14 and A 17).

Next to personal security concerns, it was predominantly social obligations towards one's loved ones that informed the decision to flee (either alone or together with their wife and children or organising the flight of a family member). Often several motives played a role as the case of A 9 illustrates. A9, a 34-year-old Pashtun male from Laghman was persecuted for working for the Afghan government. Apart from the threats, it was his desire to offer his children a life in peace and render it possible for them to educate themselves. ${ }^{28}$ "My pivotal reason for coming here was that our life was in danger, every day I received threats, only because I was working with the minister, several times I was attacked... we had no other choice than to flee. Our life was in danger. It was a matter of life and death .... I came here for the sake of my children, that they have a peaceful life, ... that they can educate themselves ... In Afghanistan it would not have been easy for them." 29

\footnotetext{
28 9 fled alone to Austria. His wife and children came to Austria after his request for a family reunion had been granted.

29 A 9 was working for the minister of education in Afghanistan. A 9 used "we" when speaking about himself. Using the plural form was common in many other interviews as well.
} 
That social obligations towards children and other family members are deemed more important than one's own wellbeing becomes apparent when considering the timing of a flight. Several of our interviewees mentioned that some time passed between a personally experienced violence or threat and the actual flight, often influenced by the fact that they were the sole or most crucial breadwinner of their family. ${ }^{30}$

Initially people tried to ignore these incidents by just staying. Only when the situation became aggravated did they decide to flee, as in the case of A 8, a 24-year-old male Pashtun from Laghman. Following several threats by the Taliban for working in UN funded development projects, A 8 was eventually taken prisoner by them. Released through the mediation of some village elders, he finally decided to leave the country. ${ }^{31}$

Sometimes persons exposed to threats attempt to minimise potential dangers by changing jobs and/ or place of work and residence, as in the case of A 19, a 29-yearold male from Kabul. Upon his return from Pakistan in 2003 where he and his family had taken refugee during the Taliban regime, he accepted several job offers from the Afghan government and US security companies (amongst others working as translator). Whenever he felt endangered due to his work, he changed his employment. In 2012 the situation worsened. He received several threatening letters at his home and workplace urging him to stop working for 'unbelievers'. In 2013 the critical point was reached when he barely escaped a Taliban attack on his car. Conferring with his family and work colleagues, he reached the decision to leave Afghanistan for good.

In many cases the final decision to actually flee was only taken when a personal threat (e.g. fear of being abducted, receiving threatening letters etc.) was perceived as not only endangering one's own life, but also that of other family members (e.g. children, parents, brothers, etc.) (cf. A 4, A 13 and A 16).

A case in point is A 13, a 36-year-old Hazara from Ghazni, who was collaborating with his paternal uncle - a human rights activist and politician - disseminating radio programmes on women's and human rights issues, something the Taliban considered as un-Islamic. A 13 received numerous threats. Eventually a Taliban court issued a death sentence. This finally motivated him to flee:

"As long as a person does not need to, he will never leave his homeland, in particular me. How can I wish to leave my wife, my son, my disabled brother ... no one acts like that... but I had no other option, the threats increased, as long as I had a chance to life, I did not emigrate, but then I came to the point, that there is no place for me there. If I remain, I will be killed, if I remain my family will still be menaced, I fled and left Afghanistan."

30 See Berg Harpviken (2009, p. 7).

31 In many parts of Afghanistan, village elders act as mediators in conflicts. For details see COBurn 2011. 
Yet, A 13's decision was also informed by his conviction to offer a better life to his son:

“... due to constant threats I was obliged to leave Afghanistan ... every father wishes the best for his children. I do not want my son to grow up in a war, in the midst of attacks and explosions. I want my son to grow up in a place, where humanity, justice and human rights prevail, where he can exercise his rights, where he can educate himself. I do not want my son to be forced to life the same kind of life I had to live. Until today I had no happy life, there was always war, I have always been threatened."

Another illustrative case is A 4, a 54-year-old male Pashtun from Kandahar, whose brother had been killed several years earlier by the Taliban. A 4 himself fell victim to a suicide attack in which he was severely wounded, losing among others the vision of one of his eyes. Yet, it was not until he was threatened that his two young children would be kidnapped for ransom that he and his family left the country. A 4 described the situation as follows:

"During the presidency of Karzai [2002 to 2014] life was good. By and by the attacks started. When we left the house, we were preoccupied with the thought that we may not return home alive. However, it was not as bad as when one day they [the Taliban] waited in front of my home and threatened my children, requesting a sum of money and urged me to stop working [he was working for a foreign organisation at the time] ... Thus, I decided to flee to Europe." 32

In line with the above mentioned case, A 4's decision to flee was motivated by his desire to offer his children a better future:

"Since I had been seven years old, blood had been spilled in Afghanistan, until today. When I consider my situation, without education, under no circumstance did I want my children to suffer the same fate. Education is very important."

Even more dramatic where developments that finally convinced A 16 (a 31-yearold Pashtun male from Laghman) to flee. Similar to other interviewees (e.g. A 2, A3 and A 4), A 16 worked for foreign organisations (e.g. NATO or GTZ) and was repeatedly exposed to threats by insurgent groups. To minimise his personal danger he changed employment and even moved from his native Laghman to Kabul. In October 2013, A 16's brother was kidnapped and remained missing for a year until his dead body was found. Assuming his employment had caused the kidnapping and subsequent murder of his brother, A 16 once again quit his job. Shortly afterwards insurgents broke into his home and injured his parents. This was the decisive moment that finally made him flee.

In fact he fled together with his wife and two sons. 
As the above cases have illustrated, social obligations towards family and kin were the major driving force in the decision-making process of whether to flee or to stay put.

Oftentimes, it is a combination of general security concerns, experienced violence, economic hardship and disillusionment, but also personal reasons, that have an impact here. In line with the overall political situation and personal living circumstances, the fulfilment of one social obligation (e.g. protecting the life on one's children) may set in motion a whole array of further obligations, eventually leading to the conviction that fleeing may be the sole way of guaranteeing survival, as the following cases illustrate.

A 6, a 33-year-old Hazara originally from Saripul and his wife A 7 (a 29-year-old Hazara born in Mazar-e-Sharif) spent several years in Iran before arriving with their three children (eight, six and two and half years old) in Austria in the autumn of 2015. In the interviews A 6 and A 7 highlighted quite different motives that informed their decision to leave Iran. The family of A 6 had fled to Iran during the Soviet occupation of Afghanistan. Despite living in Iran for 30 years, A 6 felt discriminated against as a foreigner with little opportunity to improve the living conditions of himself and his family.

"We had been living in Iran for thirty years, but we had no job perspectives. ... No matter how long Afghans had lived in Iran and how qualified they were, no value was attached to them. In the end, we wanted to offer our children a good life, that they can educate themselves, ... that they can achieve something in their life. ... Initially we thought of returning to Afghanistan, but the country is not safe, we were looking for another option, a possibility emerged ... and we came here..."

His wife, A 7, narrated the motives for their flight somewhat differently. At the same time her fate demonstrates the interdependence of social obligations prevailing in Afghan society (e.g. next to the responsibility of parents to protect the life of their children, the obligation of children, notably daughters, to obey their parents and inlaws.). The father of A 7 - a Shia Hazara - was killed by the Taliban. A 7's mother feared for the safety of her four children (next to A 7, two other daughters and a son):

"During the times of the Taliban, 10 or 15-year-old boys, ... were collected and taken away, also girls, who had a pretty face ... Many families remained without men in the house, when a man is lacking in the family, the life is very hard... my brother, who was living with us, we hid him away, so that he would stay with us. There was no mercy. They [the Taliban] aimed to eliminate all men, no Shia man was allowed to stay alive."

The mother of A 7 particularly feared her three daughters being abducted by the Taliban and fled to Iran. Having no financial means A 7's mother lent them money to finance the flight of herself and her children. She had hoped to find work in Iran to 
provide for her family and to pay back her debt, but her hopes vanished and in the end she had to give her daughter (A 7) in marriage to pay off her debt:

"The man, who is now my father-in-law, said, if you are not able to give the money, you can give your daughter ... I went to his house instead of the money. I had no choice ... my mother said, it does not matter. It is better if you go than us having to go to court. It does not matter greatly. That was my fate."

A 7 had no other option than to accept this marriage. She felt mistreated by her in-laws and was furious about her own husband rather siding with his parents than supporting her in her struggle against her mother-in-law and other members of her husband's family. Eventually A 7 had enough of the domestic quarrels and threatened to leave the family. This finally motivated her husband (A 6) to break with his family and they both left the country with their children:

"He loves his children, his father selected me, I do not know whether he loves me, but he loves his children. He said, he did not want his children to lose their mother. That is the reason why we came here."

Another case illustrating how the current/overall socio-political situation in Afghanistan may spur a whole chain of social obligations that eventually force people to flee is the story of A 10 and A 11. Following the death of her father [the cause was not mentioned in the interview] A 10, a forty-year-old well-educated Pashtun women, and her mother had to live in the household of her paternal uncle..$^{33}$ Both women felt oppressed by the household head and his wife. One day, A 10 's paternal uncle, a Taliban sympathiser - decided to marry A 10 to a "white bearded" Talib. ${ }^{34}$ Both women were shocked by the news, especially her mother, who always was of the opinion that her daughter should educate herself, something her paternal uncle did not approve of. A 10 explains her mother's worries as follows:

"... my mother was stunned, she thought, when the girl is married to that Talib he will lock her up, she will be forced to wear a burka, and who knows what else he will do with her, he will oppress her...."

Desperately trying to prevent this "forced marriage", the mother of A 10 approached a neighbour, she got things of her chest, narrating her plight as a widow. ${ }^{35}$ The neighbour

\footnotetext{
33 As A 10 had no brother to take care of her and her widowed mother, they were both forced to live with her paternal uncle. In Afghan society women are usually not allowed to live by themselves.

34 The reference "white bearded Talib" in A 10's interview indicates that her potential husband was an elderly man.

35 Afghan women, in particular widows, are often socially isolated, especially when they have no relatives living close by. Due to displacement, the general security situation, and above all the strictly required segregation of men and women in Taliban controlled areas, this isolation of women became more widespread.
} 
promised support and suggested to talk to her brother whether he would agree to give his unmarried son in marriage to A $10 .{ }^{36}$ Within a week A 10 was married to A 11, a 34-yearold male Pashtun from Jalalabad, and moved in with her in-laws. Shortly afterwards her father-in-law and her husband were threatened by her paternal uncle. Selling some of his land to finance the flight and getting in contact with a human trafficker, her husband's father facilitated their flight.

What is striking in the narrative of A 10 and A 11 is the way how they both describe the causes that led to their flight. While A 10 elaborated on the plight of her widowed mother and her own difficult life in the household of her paternal uncle and portrayed her father-in-law as the driving force that organised their flight, thereby explaining in detail all his efforts to safe her and her husband's life, the description of her husband (A 11) remained very short, highlighting however that he himself was also involved in the decision-making process to flee, but that his father had organised the flight.

A 10 explained the background of her flight as follows:

"... my father-in-law was threatened, my uncle [she refers to her paternal uncle] said, how could you take the girl, that was only engaged, without a wedding. ... My father-in-law was very rich and had a lot of land, he, to avoid a conflict, drove me to Kunar. I stayed a week in Kunar, then my father-in-law spoke to a smuggler. One week later I went to Kabul. In Kabul I spent a night in the house of a friend of my father-in-law and the next day I was sitting in an airplane...."

Her husband (A 11) recounted the story like this: “... following my engagement, I learned that she had been promised to a Talib... When he heard about this, I was threatened by the Talib. He stated that she [A 10] is his fiancé. Following that threat, they also threatened my father. Live became very hard... The Taliban threatened us. I could not continue my life there. Therefore, I took my wife and I reached the decision to leave my homeland...."

Certain social obligations (e.g. revenging the death of a close kinsmen) may also be closely linked to other social obligations (e.g. fleeing to protect one's own life or that of other relatives) as the case of A 15 (a 20-year-old Pashtun male form Laghman), vividly illustrates, who fled to escape a vendetta.

Although vendettas do occur in Afghan society, especially among Pashtun tribesmen where their customary law (the Pashtunwali, c.f. STEUL 1981) requires revenge, the primary cause that triggered this vendetta was closely embedded in the current situation of warfare in Afghanistan where Afghan governmental forces and their foreign supporters (above all US troops) were fighting Taliban insurgents. Following the defeat of the Taliban regime in 2001/2002, the Taliban have meanwhile (especially

36 In Afghanistan the parents usually decide whom a son or daughter should marry. This becomes apparent in the interview with A 11 "...for two years I had worked as a teacher and then I was engaged to a girl in Kabul..." (Afghan 11, male 34-year-old, Jalalabad, Pashtun). 
since 2009) re-emerged in many parts of the country, especially in southern and eastern Afghanistan, where they attempt to re-impose their rigid code of conduct (e.g. banning music at public and private events).

Everything started with the announcement of A 15's brother that musicians were invited to his wedding, an amusement the Taliban are strongly opposed to. Hearing about this, the Taliban warned A 15's brother of dire consequences if he went ahead. A 15 's brother, however, ignored the warnings and his parent's recommendation to give in to the Taliban order. The wedding proceeded as planned until midnight when someone started to shoot at the wedding guests. A 15 and his family did not really care about the incident. Shortly afterwards two brothers were killed by US forces in a neighbouring village. The brother of the two victims then accused the brother of A 15 of having reported his dead brothers to the Americans for having been responsible for the shooting at the wedding (which had not been the case). Eventually the brother of A 15 was killed by a relative of the two persons, who threatened to kill A 15 as well:

“... two of my brothers have been killed, 'I have already caught one [referring to the brother of A 15] and now I will kill another person', ... my father was very worried about me and stated, 'now they will also kill my other son'."

Fearing for his life A 15 's family convinced him to flee. "Before this event we had a good life, there was no need for me to come to Austria, I had a good life there, cars, my father was there, my brother was there, we had money, we had a store. I had no desire to come to Europe. After this event, my life was in danger. My parents stated that they could not protect me any longer, they urged me to go, no matter where to, most important that my life is saved. I received many threats and in the village nobody wanted to talk to me or hang out with me. They said that I had enemies and that I should stay away from them. Because of you we will get into trouble. My mother advised me to leave. We sold everything and I came here."

Despite his flight, the threats against his family continued forcing them to sell their property and to go into hiding. "...my family in Afghanistan is still in danger, we have personal enemies, sometimes here, sometimes there, my mother and my sister-in-law they change their whereabouts every second week". ${ }^{37}$ Although A 15 enjoys a life of personal safety in his Austrian exile, he feels responsible for his meanwhile widowed mother, his widowed sister-in-law (wife of his brother) and his younger brother who is now threatened with being killed. "... I feel responsible for my family and I want to take up this responsibility for my family. ... So far I was not able to support my family, for a long time I had no papers [this refers to his situation in Austria], as of late I have papers, and then, if I find work, I will definitely support my family, for I feel responsible for them..."

Grief-stricken, the father of A 15 has since died. 


\section{Supporting the flight of others: another social obligation}

The social obligation to protect the life of family and kin and to care for their wellbeing does not solely refer to one's own personal flight (e.g. fleeing to minimise potential threats for other family members who stay put). It also extends - as some of the aforementioned cases have illustrated - to the obligation to organise the flight of a relative whose life is endangered (cf. A 14) or to send a family member away offering $\mathrm{him} / \mathrm{her}$ better occupational or educational opportunities as in the case of A 17, a 21year-old male Hazara, who at the age of 17 was prompted by his father to leave Iran, where A 17 and his family were living in precarious circumstances:

“... my father thought about our future, really, for a father it is difficult to send away his own child, a father cannot really do this, but they have sent us, we were still small, move on, look that you are well... somewhere, where you can live well, here [meaning Iran] you cannot live... I went to Turkey."

Counselling also plays an important role in the context of flight-related social obligations. Several of our interviewees mentioned having sought the advice of relatives or friends as in the case of A 3, a 24-year-male Pashtun from Nangarhar. Having repeatedly been threatened by the Taliban for his work in an international organisation he turned to his father for advice:

“... [after being exposed to another threat] ... I narrated the incident to my father. He suggested that I should go a last time [to my job] and immediately resign, because these people would never leave me along. The next day I went to my job and signed my notice of termination. Then my father stated that I could not remain in Afghanistan, my life is in danger. He urged me to leave Afghanistan. Therefore I left my home country."

The obligation to support a family member, kin or friends focuses mainly on organising the flight itself. Close relatives (e.g. father, father-in-law, mother-brother, etc.) and friends provide the financial means for the flight and/ or establish contact with a human trafficker, herein often using personal networks to trace a trustworthy smuggler. Yet, the support does not stop here. It is granted throughout the whole flight process by sending money to allow the continuation of the flight, by putting a refugee in contact with acquaintances that may facilitate further movements, or by offering advice for what to do next when a problem appears. A good case in point is A 14, a 20-year-old male Shiite from Herat whose father had been killed by the Taliban. Following the death of his mother, A 14 joined the household of his maternal uncle. Still feeling threatened by the Taliban whom he despised, the husband of his maternal aunt organised his flight to Turkey. There he became acquainted with a fellow Afghan who offered him a job in his bakery. Informing his aunt about his life in Turkey: 
"... she said, that I should not stay in Turkey, I will be sent back to Afghanistan and would again fall into the hands of the murderers of my father. Therefore, she said that I should work and save money and flee to Europe."

\section{Conclusion}

Summing up the analysis of the twenty Afghan interviews the following conclusions can be drawn. Similar to other studies highlighting the reasons for taking refuge, the Afghan material clearly demonstrated that it is not one prime mover that prompts people to flee, but rather a combination of causes (e.g. experienced violence as well as economic reasons) that influence the decision to flee or to renew a flight. Personal motives as well as social obligations - both often neglected in forced migration studies - oftentimes play a decisive role as well.

Several interviewees highlighted the relevance of personal reasons (e.g. fleeing to avoid a forced marriage or to escape an ongoing vendetta). Sometimes it was these personal reasons in conjunction with other causes (e.g. persecution by the Taliban for being Shiite, fear of abduction, etc.) that motivated them to flee as in the case of A 7. Here an episode of experienced violence (the killing of her husband and father) and continued threats against a religious minority instigated the flight with a widow (A7's mother) and her children. Due to lack of personal means and a supportive network the flight could only be realised by acquiring a credit. Unable to refund the credit, A 7 was offered as a bride to settle the debt. Unhappy in this "forced marriage", she threatened to leave her children and finally convinced her husband to flee with her and their children. This case illustrates the close link between personal and other reasons for a flight. Simultaneously this case underscores that forced migrations are social processes in which agency and the existence or non-existence of social networks play an important role (cf. BAKEWELL 2011, CAstLes 2003 and Bauer in this volume).

Social obligations and their relevance in the pre-flight decision-making process as well as during the flight itself are another frequently neglected topic in forced migration studies. Our Afghan material illustrated that a vast array of different social obligations play a role here. Social obligations relevant in this context refer to the fulfilment of social norms and expectations (e.g. having to join a husband living in Austria, e.g. A 1). They also include the responsibility of protecting the life of family members (e.g. children, wife) and kinsmen and to offer them a "good life". From this stems the conviction that decisions have to be reached in a manner that allows the strongest possible congruence between social obligations and the options at hand.

The willingness to maintain commitments towards family, kinsmen and friends and to fulfil one's social obligation - even in times of protracted warfare and economic 
hardship - is particularly crucial in time of war and a failing or non-existing state as BERG HARPVIKEN (2009, p. 3) stresses: "Under such uncertain circumstances, people tend to resort to their kin and friends for information, economic assistance, and security". The Afghan interviews offer ample evidence for this. It is family, kin and friends one trusts most in uncertain times, hoping they are willing and able to fulfil social obligations crucial for one's survival. Concluding, I strongly advocate for studying the intersection of these social obligations and the reasons for fleeing when analysing processes of forced migration.

\section{References}

AsylKoordinAtion Österreich (2017), "Es gibt keine Sicherheit in Afghanistan". Asyl aktuell, 4/2016; pp.6-10.

Bakewell, O. (2011),: “Conceptualising Displacement and Migration: Processes, Conditions, and Categories"., In: Koser, Kh. and Martin S. (eds.): The Migration-Displacement Nexus, Patterns, Processes, and Policies. New York, Oxford, Berghahn Books, pp. 14-28.

Berg Harpviken C. (2009), Social Networks and Migration in Wartime Afghanistan. Houndmills, Basingstoke, New York.

BJelicA J. (2016 a), "Deciding to Leave Afghanistan (2): The routes and the Risks". Afghanistan Analyst Network, 19 May 2016; <https://www.afghanistan-analysts.org/wp-admin/post. php>

BJelica J. (2016 b), "Over Half a Million Afghans Flee Conflict in 2016: A look at the IDP statistics." Afghanistan Analyst Network, Published: 28 December 2016.

$<$ https://www.afghanistan-analysts.org/wp-admin/post.php>

$>$ https://www.afghanistan-analysts.org/over-half-a-million-afghans-flee-conflict-in-2016a-look-at-the-idp-statistics/>

BJelicA J. (2016 c), "Caught Up in Regional Tensions? The mass return of Afghan refugees from Pakistan." Afghanistan Analyst Network, Published: 22 December 2016. $<$ https://www.afghanistan-analysts.org/wp-admin/post.php>

BJeLiCA J. (2017), "Voluntary and Forced Returns to Afghanistan in 2016/17: Trends, statistics and experiences". Afghanistan Analyst Network, Published: 19 May 2017. $<$ https://www.afghanistan-analysts.org/wp-admin/post.php $>$

BMI - Sektion III Recht (Hg.) (2015), Vorläufige Asylstatistik. Vienna, December 2015. $<$ http://www.bmi.gv.at/cms/BMI_Asylwesen/statistik/files/Asylstatistik_Dezember_2015. pdf $>$

BMI - Sektion III Recht (Hg.) (2016), Vorläufige Asylstatistik. Vienna, December 2016. $<$ http://www.bmi.gv.at/cms/BMI_Asylwesen/statistik/files/2016/Asylstatistik_ Dezember_2016.pdf>

BMI - Sektion III Recht (Hg.) (2017), Vorläufige Asylstatistik. Vienna March 2017. $<$ http://www.bmi.gv.at/cms/BMI_Asylwesen/statistik/files/2017/Asylstatistik_ Maerz_2017.pdf> 
Boland K. (2010), "Children on the Move A Report on Children of Afghan Origin Moving to Western Countries", February 2010 [Retrieved 19 September 2012] $<\mathrm{http}$ //www.unicef.org/infobycountry/files/Book_children_on_the_move.pdf $>$

Brücker H., Fendel T., Kunert A., Mangold U., Siegert M., Schupp J. (2016), „Geflüchtete Menschen in Deutschland. Warum sie kommen, was sie mitbringen und welche Erfahrungen sie machen". IAB-Kurzbericht 15. Nürnberg, Bertelsmann.

Castles S. (2003), "Towards a Sociology of Forced Migration and Social Transformation". Sociology, 37 (1), pp. 13-34.

Ceung S.Yi., Phillimore J. (2013), Social networks, social capital and refugee integration. Research Report for Nuffield Foundation April 2013. University of Birmingham.

$<$ http://www.nuffieldfoundation.org/sites/default/files/files/Nuffield\%20Refugee $\% 20$ Exec\%20Summary\%20final.pdf>

Cheslow D. (2016), "Life in Limbo For Afghan Migrants In Turkey"; RFE/RL April 24, 2016. $<$ https://www.rferl.org/a/afghan-migrants-turkey-life-in-limbo/27693708.html>

Clark K. (2016), "The Bloodiest Year Yet: UN reports on civilian casualties in 2015”. Afghanistan Analyst Network, Published: 14 February 2016. $<$ https://www.afghanistan-analysts.org/wp-admin/post.php $>$

Clark K. (2017), "Looking at the 'Nicholson plan': A bid to tilt the Afghan war in the government's favour". Afghanistan Analyst Network, Published: 24 May 2017.

$<$ https://www.afghanistan-analysts.org/wp-admin/post.php?t=1495637073312>

Coburn N. (2011), "The Politics of Dispute Resolution and Continued Instability in Afghanistan". United States Institute of Peace, Special Report. <https://crossettlibrary.dspacedirect.org/ bitstream/handle/11209/10487/2011_Coburn_USIP_SR_The\%20Politics\%20of\%20 Dispute\%20Resolution.pdf? sequence $=\overline{1} \&$ isAllowed $=\mathrm{y}>$

Collective for Social Science Research (2006), “Afghans in Peshawar. Migration, Settlements and Social Networks". (Case Study Series), Kabul, AREU, January 2006. $<$ http://www.refworld.org/docid/47c3f3c45.html>

Crawley H., Duvell F., Sigona N., McMahon S., Jones K. (2016), “Unpacking a rapidly changing scenario: migration flows, routes and trajectories across the Mediterranean". MEDMIG Research Brief Nr.1: March 2016. <http://www.medmig.info/wp-content/uploads/2016/03/ MEDMIG-Briefing-01-March-2016-FINAL-1.pdf>

De Bel-Air F. (2016), "Migration profile: Syria”. Migration Policy Center, University of Florence. $<$ https://www.researchgate.net/publication/299383940_Syria_Migration_Profile>

Donini A., Monsutti A., Scalettaris G. (2016), "Afghans on the Move: Seeking Protection and Refuge in Europe. "In this journey I died several times; In Afghanistan you only die once."'. Global Migration Research Paper No. 17, 2016, Global Migration Centre, The Graduate Institute Geneva.

EASO (European Asylum Support Office) (2016), "EASO Country of Origin Information Report Afghanistan Security Situation Update". January 2016. <http://www.cgvs.be/sites/default/ files/rapporten/easo_country_of_origin_information_report_afghanistan._security_ situation.pdf>

Echavez Ch.R., Bagaporo J.L.L., Pilongo L.W.R., Azadmanesh Sh. (2014), "Why do children undertake the unaccompanied journey? Motivations for departure to Europe and other industrialised countries from the perspective of children, families and residents of sending communities in Afghanistan." Afghanistan Research and Evaluation Unit and United Nations High Commissioner for Refuees, Issues Paper. Dec. 2014.

Eurostat (2017), Asylum quarterly report. Data extracted on 15 March 2017. $<$ http://ec.europa.eu/eurostat/statistics-explained/index.php(Asylum_quarterly-report> 
FMR (Forced Migration Review) (2014), “Afghanistan's displaced people: 2014 and beyond”. FMR 46, May 2014. <http://www.fmreview.org/sites/fmr/files/FMRdownloads/en/ afghanistan.pdf>

Frud B. (2012), "Afghans Working With NATO-Led Forces Fear For The Future". Radio Free Europe/ Radio Liberty, November 21, 2012. <https://www.rferl.org/a/afghans-workingwith-nato-forces-fear-for-future/24777516.html>

Glatz A.-K. (2015), “Afghanistan: New and long-term IDP's risk becoming neglected as conflict intensifies". (IDMC $=$ Internally Displaced Monitoring Centre, $16^{\text {th }}$ July 2015). $<$ http://www.internal-displacement.org/south-and-south-east-asia/afghanistan/2015/ afghanistan-new-and-long-term-idps-risk-becoming-neglected-as-conflict-intensifies>

Goodson L. P. (2001), Afghanistan's Endless War. State Failure, Regional Politics, and the Rise of the Taliban. Seattle and London, University of Washington Press.

GrötzBach E. (1990), Afghanistan. Eine geographische Landeskunde. Darmstadt 1990.

Hansen R. (2014), "State Controls: Borders, Refugees, and Citizenship". In: Fiddian-QASMiYeH E., Loescher G., Long K., Sigona N. (eds.): The Oxford handbook of refugee and forced migration studies. Oxford [u.a.], pp. 253-264.

Healy C. (Report Author) (2016), "Targeting Vulnerabilities. The Impact of the Syrian War and Refugee Situation on Trafficking in Persons - A Study of Syria, Turkey, Lebanon, Jordan and Iraq". Briefing Paper, Prepared by the International Centre for Migration Policy Development, Vienna - Austria, January. <https://www.icmpd.org/fileadmin/ICMPDWebsite/Anti-Trafficking/Targeting_Vulnerabilities_EN_SOFT_.pdf $>$

Human Rights Watch (1998), “Afghanistan: The Massacre in Mazar-i-Sharif”. Human Rights Watch Report: November Vol. 10, No. 7.

$<$ https://www.hrw.org/legacy/reports98/afghan/Afrepor0.htm>

Human Rights Watch (2001), “Afghanistan: Massacres of Hazaras in Afghanistan”. 1 February 2001. C1301, <http://www.refworld.org/docid/3ae6a87c4.html [accessed 7 June 2017]>

Human Rights Watch (2013), “Unwelcome Guests. Iran's Violation of Afghan Refugee and Migrant Rights". Nov. 2013. $<$ https://www.hrw.org/sites/default/files/reports/iran1113_forUpload_0.pdf>

Human Rights Watch (2017), "Pakistan coercion, UN complicity. The Mass Forced Return of Afghan Refugees". February 2017.

$<$ https://www.hrw.org/sites/default/files/report_pdf/pakistan0217_web.pdf>

ICG (International Crisis Group) (2016), "Fight or Flight: The Desperate Plight of Iraq's Generation 2000". Middle East Report No 169;

$<$ https://www.crisisgroup.org/middle-east-north-africa/gulf-and-arabian-peninsula/iraq/ fight-or-flight-desperate-plight-iraq-s-generation-2000>

iOM (International Organization for Migration) (2014), "Afghanistan Migration Profile". IOM Office Kabul. <https://publications.iom.int/system/files/pdf/mp_afghanistan_0.pdf>

iOM (International Organization for Migration) (2015), "Undocumented Afghan Returns from Iran \& Pakistan. January to December 2015". IOM CBRR Annual Report 2015.

$<$ https://afghanistan.iom.int/sites/default/files/Reports/returns_of_undocumented_ afghans_from_iran_and_pakistan_annual_report_2015_0.pdf $>$

IOM (International Organization for Migration) (2016), "Migration Flows from Iraq to Europe”. February, IOM Iraqi Mission, Displacement Tracking \& Monitoring, DTM. $<$ http://www.iom.int/news/iom-surveys-iraqi-migrants-europe $>$ 
IOM (International Organization for Migration) (2017), "Return of undocumented Afghans". Weekly Situation Report, 14-20 May 2017. <https:/afghanistan.iom.int/sites/default/files/ Reports/iom_afghanistan-_return_of_undocumented_afghans_weekly_situation_report_14-20_may_2017.pdf>

Kaufmann K. (2017); “Wie nutzen Flüchtlinge ihre Smartphones auf der Reise nach Europa? Ergebnisse einer qualitativen Interview-Studie mit syrischen Schutzsuchenden in Österreich." SWS-Rundschau (Sozialwissenschaftliche Studiengesellschaft), Heft 1/2017.

KAZEMI S.R. (2016), “Afghan Exodus: Maruf's tale of an emerging transnational community between Herat and Europe". Afghanistan Analyst Network, 17 September 2016. https://www.afghanistan-analysts.org/afghan-exodus-marufs-tale-of-an-emergingtransnational-community-betweenherat-and-europe/?format=pdf

Kondova K. (2016), The smartphone as a lifeline: the impact of digital communication technologies and services on refugees' experiences during their flight. MA thesis June 2016. Master Media Studies - Media \& Business, Erasmus School of History, Culture and Communication, Erasmus University Rotterdam. <https://thesis.eur.nl/pub/34539/Kondova.pdf>

KushKaki S. (1990), “Afghan refugees: the Afghan view”. In: Anderson, E.W. and Dupree, N.H. (eds.): The Cultural Basis of Afghan Nationalism. London and New York; pp. 115-120.

Linke L. (2016), "Deciding to Leave Afghanistan (1): Motives for migration”. Afghanistan Analyst Network; Published: 8 May 2016. <https://www.afghanistan-analysts.org/wp-admin/post. php>

Locket K. (2010), "The Situation of Women and Girls in Afghanistan". In: Oeppen C. and SCHLENKHoff A. (eds.) Beyond the 'wild tribes': understanding modern Afghanistan and its diaspora, pp. 45-56, London, Hurst.

Marfleet Ph. (2011), "Displacement and the State - the Case of Iraq". In: Koser Kh. and Martin S. (eds.): The Migration-Displacement Nexus. Patterns, Processes, and Policies. New York, Oxford, pp. 96-118.

Monsutti A. (2005), War and Migration: Social Networks and Economic Strategies of the Hazaras of Afghanistan. New York \& London, Routledge.

Monsutti A. and Collective for Social Science Research (2006), "Afghan Transnational Networks: Looking Beyond Repatriation”. Synthesis Paper Series. Kabul, AREU, August 2006. <http://reliefweb.int/sites/reliefweb.int/files/resources/6A583751924F6A31492571 F400099A52-areu-afg-31 aug.pdf>

Monsutti A. (2016), "Les Afghan et la 'Crise' des Refugiés en Europe”. In: Schweizerisches Komitee zUR UnterstütZung des afghanischen Volkes (ed.), Afghanistan Informationen, No. 78, März 2016, p. 15 seq.

Muzhary F. (2017), "Resettling Nearly Half a Million Afghans in Nangrahar: The consequences of the mass return of refugees". Afghanistan Analyst Network, Published: 12 May 2017. $<$ https://www.afghanistan-analysts.org/wp-admin/post.php>

Norwegian Refugee Council (2017), "Hundreds of Afghan families are desperately fleeing armed conflict in Kunduz Province". Published 7 May 2017. [retrieved 02.06.2017]

$<$ https://www.nrc.no/news/2017/may/afghanistanthousands-flee-armed-conflict-inkunduz/>

OCHA (UN OfFice for the Coordination of Humanitarian Affairs) (2015), Afghanistan. Human Needs Overview 2016. (published in Nov. 2015). <https://www.humanitarianresponse.info/ system/files/documents/files/afg 2016 hno final 20151209.pdf> 
OCHA (UN Office for the Coordination of Humanitarian Affairs). (2016), Afghanistan Humanitarian Needs Overview 2017. (Published in Nov. 2016).

$<$ http://reliefweb.int/sites/reliefweb.int/files/resources/afg_2017_hno_english.pdf $>$

OCHA (UN Office for the Coordination of Humanitarian Affairs) (2017 a), Afghanistan Conflict Induced Displacement (as of 30 April 2017). <http://reliefweb.int/map/afghanistan/ afghanistan-conflict-induced-displacements-30-april-2017>

$<$ http://reliefweb.int/sites/reliefweb.int/files/resources/afg_idp_situation_response_ dashboard_20170430.pdf $>$

OCHA (UN Office for the Coordination of Humanitarian Affairs) (2017 b), Afghanistan Conflict Induced Displacement (as of 21 May 2017). <http://reliefweb.int/map/afghanistan/ afghanistan-conflict-induced-displacements-21-may-2017>

OCHA (UN Office for the Coordination of Humanitarian Affairs) (2017 c), Pakistan: Afghan Refugees and Undocumented Afghans Repatriation. (21 - 27 May 2017).

$<$ https://www.humanitarianresponse.info/system/files/documents/files/afghan returns_20170523_0.pdf $>$

Pro Asyl (2016), Afghanistan: Kein sicheres Land für Flüchtlinge. Eine Recherche zur politischen und ökonomischen Situation im Land, zur Sicherheitslage und zur Situation der Flüchtlinge. (published Aug. 2016). <https://www.proasyl.de/wp-content/uploads/ 2016/08/PROASYL_Afghanistan_Broschuere_Jul16.pdf $>$

RiESENKAMPFF M. and Noor EBAD A. (2017), „Die aktuelle Migration aus Afghanistan: Hintergründe und Ursachen“. Länderberichte Konrad-Adenauer-Stiftung e.V. Februar 2017. <http:// www.kas.de/afghanistan/de/publications/48261/>

Rohde M., Aal K., Misaki K., Randall D., Weibert A., Wulf V. (2016), “Out of Syria: Mobile Media in Use at the Time of Civil War". International Journal of Human-Computer Interaction, Vol. 32, No. 7, pp. 515-531. <http://dx.doi.org/10.1080/10447318.2016.1177 $30>$

Ruttig T. (2015), "Rights \& Freedoms: An “Afghan Exodus": Facts, figures, trends.” Afghanistan Analysts Network, 14. Nov. 2015.

$<$ https://www.afghanistan-analysts.org/an-afghan-exodus-facts-figures-trends/>

Ruttig T. (2017), "Afghan Exodus: Afghan asylum seekers in Europe (3) - case study Germany”. Afghanistan Analyst Network, Published: 17 February 2017. https://www.afghanistan-analysts.org/wp-admin/post.php

SaIto M. (2007), "Second-Generation Afghans in Neighbouring Countries: From Mohajer to Hamwatan: Afghans Return Home”. Kabul: AREU, 2007.

SaIto M. (2009), "Searching for My Homeland: Dilemmas Between Borders. Experiences of Young Afghan Returning "Home" From Pakistan and Iran". Afghanistan Research and Evaluation Unit, Synthesis Paper Series. July 2009.

Saito, M. and Hunte, P. (2007), "To return or to remain: The Dilemma of Second-Generation Afghans in Pakistan". Case Study Series, Afghanistan Research and Evaluation Unit. $<$ http://www.unhcr.org/46767c7e2.pdf $>$

Samuel Hall Consulting (2014), "Displacement Dynamics: IDP Movement Tracking, Needs and Vulnerability Analysis, Herat and Helmand". Commissioned by the International Organization for Migration (IOM), Kabul.

$<$ http://samuelhall.org/wp-content/uploads/2014/05/IDP-Movement-Tracking-Needs-andVulnerability-Analysis-Afghanistan.pdf $>$

Sigar (Special Inspector General for Afghanistan Reconstruction Report) (2015), Afghan Refugees and Returnees: Corruption and Lack of Afghan Ministerial Capacity Have 
Prevented Implementation of a Long-term Refugee Strategy. August. $<$ https://www.sigar.mil/pdf/audits/SIGAR-15-83-AR.pdf $>$

SigAR (Special Inspector General for Afghanistan Reconstruction Report) (2017), Quarterly Inspector General for Afghanistan Reconstruction; Jan. 30, 2017.

$<$ https://www.sigar.mil/pdf/quarterlyreports/2017-01-30qr.pdf>

SLIwINSKi M.K. (1988), “Afghanistan 1978-87, War, Demography and Society". Central Asian Survey, Incidential Papers Series, No.6.

Spiegel online (2013), “A Question of Morality Germany's Afghan Staff Fear Reprisals”. Spiegel online, April 26th, 2013. <http:/www.spiegel.de/international/world/afghan-employeesof-german-military-face-threats-from-taliban-a-894494.html>

Steul W. (1981), Das Paschtunwali - ein Ehrenkodex und seine rechtliche Relevanz. Wiesbaden, Franz Steiner Verlag.

Stigter E. and Monsutti A. (2005), "Transnational networks: recognizing a regional reality". Afghanistan Research and Evaluation Unit (AREU), Kabul.

The Telegraph (2017), "The Afghan Nato interpreters forced to walk through Europe for refugee status". The Telegraph, June 3rd, 2017.

$<$ http://www.telegraph.co.uk/news/worldnews/europe/serbia/11878114/The-Afghan-Natointerpreters-forced-to-walk-through-Europe-for-refugee-status.html $>$

Unama (Human Rights Unit of the United Nations Assistance Mission in Afghanistan) (2017 a), Afghanistan Annual Report on Protection of Civilians in Armed Conflict: Annual Report 2016. Kabul, Afghanistan February 2017.

$<$ https://unama.unmissions.org/sites/default/files/protection_of_civilians_in_armed_ conflict_annual_report_2016_final280317.pdf>

Unama (Human Rights Unit of the United Nations Assistance Mission in Afghanistan) (2017 b), Afghanistan Annual Report on Protection of Civilians in Armed Conflict: Annual Report 2016. UNAMA First Quarter 2017 Civilian Casualty Data. Kabul, Afghanistan April 27 $7^{\text {th }}$, 2017. <https://unama.unmissions.org/sites/default/files/27_april_2017_-_unama_first_ quarter_2017_civilian_casualty_data_english.pdf>

UNHCR (2010), Trees Only Move in the Wind A Study of Unaccompanied Afghan Children in Europe. Christine MOUGNE (author of report). Geneva, Policy Development and Evaluation Service, 2010. Retrieved 19 September 2012 from <http://www.unhcr. org/4c1229669.html>.

UNHCR (2013), UNHCR country operations profile - Islamic Republic of Iran. <http://www. unhcr.org/pages/49e486f96html>

UNHCR (2015), UNHCR Global Appeal 2015. Afghanistan Update. $<$ http://www.unhcr.org/publications/fundraising/5461 e6090/unhcr-global-appeal-2015update-afghanistan.html>

Van Hear N.( 2014), "Refugees, Diasporas, and Transnationalism". In: Fiddian-QASmiYeh E. Loescher G., Long K., Sigona N., (eds.): The Oxford handbook of refugee and forced migration studies. Oxford [u.a.]; pp. 176-187.

Witterborn S. (2015), "Becoming (Im)Perceptible: Forced Migrants and Virtual Practice". Journal of Refugee Studies, Vol. 28, No. 3; pp. 350-367. < doi:10.1093/jrs/feu036> 